Zeszyty Prawnicze

14.2 / 2014

\title{
GRZEGORZ JĘDREJEK
}

Uniwersytet Kardynała Stefana Wyszyńskiego

\section{WYNAGRODZENIE DOZORCY RZECZY RUCHOMYCH W POSTĘPOWANIU EGZEKUCYJNYM}

\section{UWAGI WSTĘPNE}

Co do zasady zajęte ruchomości zostają pozostawione przez komornika we władaniu osoby, u której został zajęte. W art. 855 k.p.c. dopuszcza jednak ustawodawca oddanie przez komornika zajętych ruchomości innej osobie, nie wyłączając wierzyciela, która pełni obowiązki dozorcy. Poza zakresem artykułu pozostaje sprawowanie dozoru przez samego dłużnika ${ }^{1}$. Przeprowadzone rozważania mają także zastosowanie do wydatków związanych z przechowaniem rzeczy jakie poniósł dozorca.

Celem artykułu jest wyjaśnienie wątpliwości co do wynagrodzenia dozorcy, które dotyczą przede wszystkim dopuszczalności dochodzenia przez dozorcę wynagrodzenia poza postępowaniem egzekucyjnym, w drodze odrębnego procesu². Pojawiające się wątpliwości

$1 \quad$ W takim przypadku dłużnik nie może żądać zwrotu wydatków związanych z przechowywaniem oraz wynagrodzenia za dozór. Wynagrodzenia i zwrotu wydatków nie mogą także żądać członkowie rodziny dłużnika, którzy wspólnie z nim mieszkają oraz osoba trzecia, u której rzecz została zajęta (art. 858 k.p.c.).

2 Postanowieniem z dnia 24 października 2012 r., III CZP 54/12, «Lex» nr 1254691, SN odmówił udzielenia odpowiedzi na dwa zagadnienia prawne przedstawione przez SA w Łodzi: „Czy w razie niepobrania przez komornika zaliczki na wynagrodzenie za dozór zajętych ruchomości, przyznanego dozorcy w postępowaniu egzekucyjnym postanowieniami sądu 
dotyczą stosowania przepisów regulujących umowę przechowania do dozorcy, któremu została oddana zajęta rzecz ruchoma. W artykule wykluczono możliwość dochodzenia przez dozorcę wynagrodzenia w procesie, jeżeli rzecz została oddana pod dozór przez komornika. Nie ma natomiast przeszkód, ażeby dozorca dochodził wynagrodzenia od wierzyciela, który oddał jemu rzecz na przechowanie. Odpowiedź na pytanie dotyczące możliwości dochodzenia przez dozorcę zajętej ruchomości wynagrodzenia od wierzyciela, zakłada konieczność określenia stosunku prawnego, będącego skutkiem oddania rzeczy ruchomej pod dozór. Należy pamiętać, że dozorcą może być także sam wierzyciel. Rozważania dotyczące tego zagadnienia zawarte zostały w części pierwszej opracowania. Część druga przedstawia wynagrodzenie dozorcy jako jeden z kosztów egzekucji komorniczej. Kolejna część, trzecia, zawiera argumenty przeciwko możliwości dochodzenia wynagrodzenia dozorcy w procesie cywilnym, jeżeli stanowi ono jeden z kosztów egzekucji. W części czwartej opracowania wskazano na możliwość obciążenia kosztami egzekucji, w postaci wynagrodzenia dozorcy, wierzyciela.

2. Charakter StosunKu PRAWNEGo MięDZy KOMORNIKIEM A DOZORCĄ ZAJĘTYCH RUCHOMOŚCI

Nie budzi wątpliwości, że komornik oddając rzecz ruchomą pod dozór na podstawie art. 855 k.p.c. wydaje postanowienie, w którym wskazuje osobę dozorcy ${ }^{3}$. Z brzmienia art. 855 k.p.c. wynika, że ko-

i komornika, nie określającymi podmiotu zobowiązanego do wypłaty wynagrodzenia, dozorca jest uprawniony do dochodzenia w odrębnym postępowaniu zapłaty tego wynagrodzenia od wierzyciela? W przypadku udzielenia pozytywnej odpowiedzi na powyższe pytanie: $\mathrm{Z}$ jaką chwilą roszczenie dozorcy do wierzyciela o wypłatę wynagrodzenia za dozór staje się wymagalne i w jakim terminie dochodzi do jego przedawnienia oraz czy postanowienie ustalające wynagrodzenie dozorcy przerywa bieg przedawnienia tego roszczenia?"

3 Por. D. Zawistowski, [w:] Kodeks postepowania cywilnego. Komentarz, red. H. Dolecki i T. Wiśniewski, IV, Warszawa 2011, s. 360; Z. Świeboda, Komentarz do kodeksu postępowania cywilnego. Część druga. Postępowanie zabezpieczające i egzekucyjne, Warszawa 2004, s. 214. 
mornik doręcza dozorcy protokół zajęcia. Powinien również doręczyć odpis postanowienia o ustanowieniu dozorcy ${ }^{4}$.

W art. 856 k.p.c. ustawodawca dookreślił obowiązki dozorcy. Pierwszy z nich polega na przechowaniu oddanych pod dozór ruchomości z taką starannością, aby nie straciły na wartości, i oddaniu ich na wezwanie komornika lub stosownie do orzeczenia sądu albo na zgodne wezwanie obu stron. Drugi obowiązek, wskazany w art. 856 $\S 2$ k.p.c., dotyczy zawiadomienia komornika o zamierzonej zmianie miejsca przechowania ruchomości. Dozorca ponosi odpowiedzialność za niezachowanie należytej staranności (art. 857 k.p.c.). Na podstawie art. 858 k.p.c. może żądać zwrotu wydatków związanych z przechowywaniem oraz wynagrodzenia za dozór odpowiednio do poniesionych trudów.

Stosunek prawny będący skutkiem oddania zajętej rzeczy ruchomej w dozór był przedmiotem wypowiedzi tak doktryny jak i orzecznictwa. Zgodnie z poglądem wyrażonym przez E. Wengerka, do stosunku między dozorcą a stronami postępowania egzekucyjnego „odpowiednie zastosowanie mają przepisy kodeksu cywilnego o przechowaniu (art. 835 - 845)"'5. W wyroku z dnia 26 kwietnia 1966 r., I CR 312/63, «Lex» nr 438, SN przyjął, że: „Z aktem powołania na dozorcę w trybie art. 596 § 3 d. k.p.c. łączy się powstanie określonych przez ustawę obowiązków i uprawnień osoby, która na objęcie dozoru wyraziła zgodę. Przy ocenie prawidłowości wykonania tych obowiązków w granicach określonych przez art. 598 d. k.p.c. stosuje się art. 239 i n. k.z., tak jak gdyby dozorca zobowiązany był na mocy umowy".

Należy wyraźnie podkreślić, że wymienione wyżej stwierdzenia w żadnym wypadku nie uzasadniają poglądu, zgodnie z którym oddanie zajętej rzeczy ruchomej dozorcy przez komornika prowadzi do powstania stosunku cywilnoprawnego, którego źródłem jest umowa przechowania. W powołanym już wyroku SN stwierdził, że przepisy kodeksu zobowiązań z 1933 r., który obowiązywał przed wejściem

\footnotetext{
4 H. Pietrzkowski, [w:] Kodeks postępowania cywilnego. Komentarz. Postępowanie egzekucyjne, red. T. ERECIŃSKI, IV, Warszawa 2011, s. 337.

5 E. Wengerek, Postępowanie zabezpieczajace i egzekucyjne. Komentarz do części II i III k.p.c., wydanie uaktualnione pod redakcją M. RoMAŃSKIEJ, Warszawa 2009, s. 383.
} 
w życie kodeksu cywilnego z 1964 r., stosuje się przy ocenie wykonania obowiązków dozorcy. Z kolei E. Wengerek dopuszczał możliwość stosowania przepisów regulujących umowę przechowania, ale wyłącznie do stosunku między dozorcą a stroną postępowania egzekucyjnego. Stronami postępowania egzekucyjnego jest wierzyciel i dłużnik. Stroną nie jest natomiast komornik oraz dozorca zajętej ruchomości.

Jednoznaczne stanowisko zajął natomiast J. Napierała, który podkreśla, iż źródłem powstania obowiązku przechowania jest umowa lub inne zdarzenie prawne 6 . Według Autora oddanie „na przechowanie” przez komornika na podstawie art. 855 k.p.c. zajętej rzeczy ruchomej stanowi przykład powstania stosunku zobowiązaniowego, którego źródłem jest zarządzenie komornika o ustanowieniu dozorcy oraz zgoda dozorcy na pełnienie obowiązków i objęcie rzeczy w dzierżenie ${ }^{7}$. Źródło takie określa J. Napierała jako „quasi umowę między komornikiem a dozorcą". Tym samym nawiązuje autor do znanego prawu rzymskiemu podziału na cztery źródła powstania zobowiązań ${ }^{8}$.

Powyższe stanowisko może budzić zastrzeżenia. W orzecznictwie SN zgodnie przyjmuje się, że stosunek między komornikiem a stronami (uczestnikami) postępowania egzekucyjnego ma charakter publicznoprawny ${ }^{9}$. Nie budzi wątpliwości, że dozorca zajętej ruchomości jest uczestnikiem postępowania egzekucyjnego ${ }^{10}$.

6 J. Napierala, [w:] System Prawa Prywatnego, VII: Prawo zobowiazań - część szczegółowa, red. J. RAJski, Warszawa 2004, s. 618.

7 Tamże, s. $621 \mathrm{i} \mathrm{n.}$

8 Por. m.in. C. Kunderewicz, Rzymskie prawo prywatne, Łódź 1995, s. 123.

9 Zdaniem SN stosunki powstające między organem procesowym (egzekucyjnym) a stroną (innym uczestnikiem postępowania) nie mają charakteru cywilnoprawnego, lecz publicznoprawny, w ramach którego nie ma mowy o równości podmiotów, lecz występuje podporządkowanie stron sądowi, względnie innemu organowi procesowemu bądź egzekucyjnemu. Por. m.in. uzasadnienie postanowienia z dnia 3 kwietnia 1974 r., II CZ 39/74, «OSNCP» 6/1975, poz. 93; uchwała SN z dnia 28 listopada 1974 r., III CZP 76/74, «OSNCP» 7-8/1975, poz. 108; postanowienie SN z dnia 28 maja 1997 r., III CKU 24/97, «OSP» 3/1998, poz. 61; uchwała SN z dnia 20 kwietnia 2006 r., III CZP 20/06, «Lex» nr 177078.

10 Zob. m.in. A. MarCinIAK, Sądowe postepowanie egzekucyjne, Warszawa 2011, s. 129. 
Analiza przepisów k.p.c. regulujących egzekucję z ruchomości prowadzi do wniosku, iż stosunek między komornikiem a dozorcą nie jest oparty na zasadzie równorzędności podmiotów ${ }^{11}$. W doktrynie i orzecznictwie podkreśla się, że na komorniku spoczywa obowiązek kontroli wykonywania dozoru ${ }^{12}$. Niedopuszczalne jest zatem odpowiednie stosowanie przepisów regulujących umowę przechowania do stosunków o charakterze publicznoprawnym, które nie są oparte o zasadę równorzędności podmiotów.

Kolejne zagadnienie, które może budzić wątpliwości dotyczy odpowiedzi na pytanie, czy oddanie rzeczy na przechowanie przez komornika prowadzi do powstania stosunku przechowania między dozorcą a wierzycielem, jako stroną postępowania egzekucyjnego.

$\mathrm{Na}$ powyższą wątpliwość należy udzielić odpowiedzi negatywnej z następujących przyczyn.

Po pierwsze, jedną z zasad prawa cywilnego jest zasada autonomii woli, która zakłada, że osoba ma wybór co do tego, czy dokonać czynności prawnej ${ }^{13}$. Z pewnością obejmuje ona również wybór co do osoby kontrahenta. W przypadku egzekucji z ruchomości wyboru dozorcy dokonuje komornik, który podejmuje decyzję o oddaniu rzeczy ruchomej w dozór w formie postanowienia ${ }^{14}$. Za brak staranności w wyborze dozorcy w przypadku szkody odpowiada solidarnie Skarb Państwa wraz z komornikiem (art. 23 u.k.s.e. $\left.{ }^{15}\right)^{16}$. Trudno jest zatem mówić o umowie przechowania między wierzycielem a dozorcą.

11 Zgodnie z art. 860 k.p.c. komornik może z ważnych przyczyn zwolnić dozorcę i ustanowić innego. Zmianę dozorcy komornik zarządzi po wysłuchaniu stron, chyba że natychmiastowa zmiana jest konieczna. Dozorca obowiązany jest po ustaniu dochodu złożyć komornikowi rachunek z dochodów (art. 862 § 1 k.p.c.).

12 Por. m.in. K. Flaga-GieruszyńsKa, [w:] Kodeks postępowania cywilnego. Komentarz, red. A. ZIELIŃSKI, Warszawa 2011, s. 1378.

13 Zob. szerzej co do samej zasady A. Stelmachowski, Zarys teorii prawa cywilnego, Warszawa 1998, s. 83 i n.

14 E. WengereK, op. cit., s. 382.

15 Ustawa z dnia 29 sierpnia 1997 r. o komornikach sądowych i egzekucji, t. jedn. Dz.U. z 2011 r. Nr 231, poz. 1376.

16 E. WengereK, op. cit., s. 382. 
Po drugie, postępowanie egzekucyjne prowadzi komornik, a nie wierzyciel. Stosownie do art. 758 i nast. k.p.c. oraz art. 2 ust. 1 i 3 u.k.s.e., komornik stanowi organ postępowania egzekucyjnego, do którego należą sprawy egzekucyjne, dokonuje zarazem czynności egzekucyjnych. Komornik jest funkcjonariuszem publicznym (art. 1 u.k.s.e.).

Po trzecie, decyzje o oddaniu zajętej ruchomości w dozór osobie niebędącej dłużnikiem podejmuje komornik „z ważnych przyczyn” (art. $855 \S 1$ k.p.c.). Decyzji takiej nie może zatem podjąć wierzyciel. Zgodnie z art. 860 k.p.c. komornik może z ważnych przyczyn zwolnić dozorcę i ustanowić innego. Zmianę dozorcy komornik zarządzi po wysłuchaniu stron, chyba że natychmiastowa zmiana jest konieczna. A zatem to komornik decyduje o powołaniu oraz odwołaniu dozorcy. W drugim przypadku opinia wierzyciela nie jest dla komornika wiążąca.

Po czwarte, przepisy k.c. regulujące umowę przechowania mogą mieć zastosowanie do relacji między komornikiem a dozorcą, a nie wierzycielem a dozorcą. Przykładowo, zgodnie z art. 844 § 1 k.c. składający może w każdym czasie żądać zwrotu rzeczy oddanej na przechowanie. Przepisy dotyczące składającego w umowie przechowania nie mogą być stosowane odpowiednio do wierzyciela, albowiem jak zaznaczono, rzecz oddaje pod dozór komornik, a nie wierzyciel. Zwrotu rzeczy oddanej pod dozór nie może żądać wyłącznie wierzyciel (art. $856 \S 1$ k.p.c.).

Oddanie ruchomości przez komornika dozorcy nie prowadzi do powstania stosunku prawnego między dozorcą a wierzycielem. W szczególności nie można mówić o zawarciu, także w sposób dorozumiany, umowy przechowania. Komornik stanowi organ egzekucyjny prowadzący, a nie nadzorujący egzekucję. Umowa taka byłaby możliwa wówczas, jeżeli postępowanie egzekucyjne prowadziłby wierzyciel. Za dopuszczalne należy jednak uznać zawarcie umowy przechowania między wierzycielem a dozorcą. W powyższej sytuacji wynagrodzenie dozorcy nie mieści się jednak w ramach kosztów egzekucji.

Inna sytuacja powstanie wówczas, jeżeli dozorcą został ustanowiony wierzyciel. Może powstać wątpliwość, czy dochodzi w takiej 
sytuacji do powstania stosunku prawnego między wierzycielem a dłużnikiem, do którego należałoby stosować odpowiednio przepisy o umowie przechowania. Należy przyjąć, iż w powyższym przypadku nie powstaje stosunek między wierzycielem a dłużnikiem, a jedynie między wierzycielem - dozorcą a komornikiem, który ma charakter publicznoprawny. Zgodnie z art. 857 § 2 k.p.c. dłużnikowi nie przysługuje roszczenie do wierzyciela z powodu uszkodzenia lub zaginięcia zajętych ruchomości podczas ich przewożenia, przesyłki lub przechowywania u dozorcy.

\section{WYNAGRODZENIE DOZORCY JAKO KOSZT EGZEKUCJI}

Na podstawie art. 858 k.p.c.: „§ 1. Dozorca może żądać zwrotu wydatków związanych z przechowywaniem oraz wynagrodzenia za dozór odpowiednio do poniesionych trudów. Nie dotyczy to dłużnika, członków jego rodziny wspólnie z nim mieszkających oraz osoby trzeciej, u której rzecz zajęto. § 2. Sumę wydatków i wysokość wynagrodzenia ustala komornik, o czym zawiadamia strony i dozorcę". Zgodnie z § 68 Rozporządzenia Ministra Sprawiedliwości w sprawie czynności komorników z dnia 9 marca 1968 r. ${ }^{17}$, regulującego dozór ruchomości, „Oddając zajętą ruchomość pod dozór komornik pouczy dozorcę o jego obowiązkach i w razie potrzeby ustali wynagrodzenie dozorcy, biorąc pod uwagę rodzaj i wartość ruchomości, warunki dozoru i czas jego trwania".

A zatem wysokość wynagrodzenia zobowiązany jest ustalić komornik. Powyższy pogląd powszechnie przyjmuje doktryna ${ }^{18}$. W uzasadnieniu uchwały z dnia 20 października 2010 r., III CZP 71/10, «Lex» nr 604067, SN stwierdził m.in.: „Artykuł 770 k.p.c. nakłada na komornika obowiązek wydania postanowienia o ustaleniu kosztów egzekucji, gdy do niego należy jej przeprowadzenie. Wymaganie to jest istotne nie tylko z punktu widzenia interesów stron, które mają

17 Dz.U. z 1968 r.,nr10, poz. 52.

18 Z. Świeboda, op. cit., s. 218. Zob. także, E. Wengerek, op. cit., s. 386. 
możliwość skorzystania ze środków zaskarżenia w przypadku wadliwego ustalenia tych kosztów przez komornika, ale także samego komornika, któremu na podstawie regulacji szczególnej zawartej art. 770 k.p.c. również przysługuje zażalenie na postanowienie sądu w tym zakresie, mimo że nie jest stroną postępowania egzekucyjnego" Powyższe stanowisko podtrzymał SN w wyroku z dnia 10 marca $2011 \mathrm{r}$., V CSK 300/10, «Lex» nr 1129173.

Zgodnie z art. 859 k.p.c. „Na postanowienie sądu co do zwrotu wydatków i wynagrodzenia dozorcy przysługuje zażalenie".

W doktrynie podkreśla się, że: ,zażalenie przysługuje na postanowienie sądu ustalające wydatki i wynagrodzenie, jak i oddalające skargę"19. Nie budzi przy tym wątpliwości, że: „,na postanowienie komornika wydawane na podstawie art. $858 \S 2$ przysługuje skarga na czynności komornika, ponieważ ich wydanie należy do czynności egzekucyjnych"20.

Kolejne zagadnienie dotyczy zaliczenia wynagrodzenia dozorcy do kosztów egzekucji komorniczej, na które składają się wydatki poniesione przez komornika (art. 39 i nast. u.k.s.e.) oraz opłaty egzekucyjne (art. 43 i nast. u.k.s.e.) ${ }^{21}$.

Zgodnie z art. 39 ust. 1 u.k.s.e.: „Komornikowi należy się zwrot wydatków gotówkowych poniesionych w toku egzekucji tylko w zakresie określonym ustawą". Jako jeden z wydatków ustawodawca wymienił w art. 39 ust. 2 pkt 4 należności osób powołanych, na podstawie odrębnych przepisów, do udziału w czynnościach. Pobrania zaliczki dotyczy art. 40 u.k.s.e.

Nie budzi wątpliwości, że wynagrodzenie dozorcy zajętej ruchomości oraz zwrot poniesionych przez niego wydatków stanowią składnik kosztów egzekucji ${ }^{22}$. Wynagrodzenie dozorcy, jako koszt egzekucji,

19 Z. Świeboda, , op. cit., s. 218.

20 D. ZawistowsKi, , op. cit., s. 363.

21 Zob. uzasadnienie uchwały SN z dnia 28 kwietnia 2005 r., III CZP 22/05, «Lex» nr148144. Pojęcie kosztów egzekucji komorniczej jest węższe od pojęcia kosztów postępowania egzekucyjnego, które oprócz wydatków i opłat obejmują także należności wierzyciela (jego pełnomocnika). Zob. H. Pietrzkowski, op. cit., s. 67.

22 A. AdamczuK, [w:] Kodeks postępowania cywilnego. Komentarz, II, red. M. MANOWSKA, Warszawa 2011, s. 574. 
zgodnie z art. 770 k.p.c. obciąża co do zasady dłużnika, ale w razie bezskuteczności egzekucji z ruchomości, koszty dozoru poniesie ostatecznie wierzyciel (art. 42 ust. 2 zd. 1 u.k.s.e.) ${ }^{23}$.

Panuje zgodność, że ustalenie kosztów postępowania egzekucyjnego może nastąpić w zasadzie dopiero po zakończeniu egzekucji, bowiem dopiero wówczas wiadomo, jakie koszty zostały poniesione (uchwała Sądu Najwyższego z dnia 29 grudnia 1995 r., III CZP 182/95, «OSNC»1996, nr 6, poz. 76; uchwała SN z dnia 13 lipca 2011 r., III CZP 37/11, «Lex» nr 852348).

Wynagrodzenie dozorcy ruchomości ściągane jest w trybie art. $770^{1}$ k.p.c., czyli na podstawie postanowienia komornika ${ }^{24}$.

\section{DochodZENIE WYNAGRODZENIA PRZEZ DOZORCE}

W artykule przyjęto pogląd, zgodnie z którym niedopuszczalne jest dochodzenie w oddzielnym procesie wydatków, stanowiących jeden ze składników kosztów egzekucji. Na aprobatę zasługuje zatem

23 S. CieślaK, [w:] Kodeks postępowania cywilnego. Postępowanie egzekucyjne. Komentarz do artykutów 758-1088, red. J. JANKOwsKi, Warszawa 2011, s. 633.

24 Jak podkreślił SN w uzasadnieniu uchwały z dnia 13 lipca 2011 r., III CZP 37/11, «Lex» nr 852348: „w przepisach art. 770 i 770¹ k.p.c. występuje istotna różnica terminologiczna. W art. 770 k.p.c. chodzi o ,ściągnięcie kosztów” wraz z dochodzonym roszczeniem, w art. $770^{1}$ k.p.c. zaś o wykonanie postanowienia komornika w przedmiocie kosztów, stanowiącego podstawę do ich wyegzekwowania. Koszty wskazywane w zawiadomieniu o wszczęciu egzekucji ściąga się wraz z dochodzonym roszczeniem, nie podlegają one zaś egzekucji. Ściągnięcie kosztów jest czynnością faktyczną, a jej dokonanie wynika z ustawy z dnia 29 sierpnia 1997 r. o komornikach i egzekucji sądowej (tekst jedn. Dz.U. z 2006 r.nr167, poz. 1191; dalej: u.k.e.). Ustawa ta określa wysokość opłaty egzekucyjnej, nie pozostawiając komornikowi swobody także co do samego faktu jej pobrania. Sąd Najwyższy w uchwale z dnia 22 października 2002 r., III CZP 65/02 («OSNC» 7-8/2003, poz. 100) wskazał, że opłata egzekucyjna jest należnością przymusową, a żądanie jej uiszczenia jest realizacją uprawnienia o charakterze publicznoprawnym. Pobieranie zatem takiej opłaty, ściąganej wraz z dochodzonym roszczeniem, następuje bez potrzeby wydawania postanowienia o ustaleniu kosztów i prowadzenia osobnej egzekucji w celu ich ściągnięcia. Takie stanowisko prezentowane jest także w doktrynie". 
stanowisko zawarte w orzecznictwie $\mathrm{SN}^{25}$. Pogląd, zgodnie z którym dozorca zajętych ruchomości może dochodzić wynagrodzenia jedynie w toku postępowania egzekucyjnego, akceptuje również doktryna ${ }^{26}$.

Za powyższym stanowiskiem przemawia przede wszystkim, jak wskazano to wcześniej w artykule, charakter publicznoprawny postępowania egzekucyjnego. Stosunek między komornikiem a uczestnikami postępowania nie ma charakteru cywilnoprawnego. Należy zatem przyjąć, że wynikłe z tego stosunku koszty nie mogą być dochodzone w drodze odrębnego procesu cywilnego ${ }^{27}$.

Brzmienie przepisów k.p.c. regulujących ponoszenie kosztów egzekucji wyraźnie wskazuje na wyłączenie możliwości ich dochodzenia w procesie cywilnym. Nie budzi wątpliwości, że wynagrodzenie dozorcy stanowi jeden z kosztów egzekucji, który ustalany jest postanowieniem komornika wydanym na podstawie art. 770 k.p.c.

${ }^{25}$ Zgodnie z tezą wyroku SN z dnia 21 września 2005 r. V CK 139/05, «Lex» nr 186929: „Koszty postępowania sądowego są definitywnie rozliczane w tym postępowaniu i nie mogą być dochodzone w odrębnym procesie". Zgodnie z wyrokiem SN z dnia 14 czerwca 1973 r., I CR 250/73, «Lex» nr 1673, celowe koszty egzekucyjne powinny być ustalone $\mathrm{w}$ postępowaniu egzekucyjnym, $\mathrm{z}$ którego wynikły (powyższy pogląd zaakceptował SN w uzasadnieniu uchwały z dnia 1 czerwca 2007 r., III CZP 37/07, «Lex» nr 259717). W uzasadnieniu postanowienia z dnia 29 listopada 2005 r., III CZP 102/05, «Lex» nr 177297, SN odmawiając odpowiedzi na zagadnienie prawne wskazał na niedopuszczalność dochodzenia w procesie odszkodowawczym kosztów egzekucyjnych. Zdaniem SN: „Podobnie należy ocenić objętą omawianym pytaniem kwestię, czy możliwe jest rozstrzyganie o kosztach egzekucji poza postępowaniem egzekucyjnym, zwłaszcza, czy dłużnik egzekwowany może na drodze procesu dochodzić od wierzyciela zwrotu kosztów egzekucji niecelowej jako odszkodowania. Również w tym wypadku - wobec wyraźnego zaaprobowania przez Sąd zgodnego stanowiska doktryny i judykatury, że w przedmiocie kosztów egzekucyjnych należy orzekać w ramach postępowania egzekucyjnego - nie wiadomo, na czym polegają jego poważne wątpliwości”.

${ }_{26}$ Por. J. JanKowsKI, [w:] Kodeks postępowania cywilnego. Komentarz, II, red. K. Piasecki, Warszawa 1997, s. 899; D. Zawistowski, , op. cit., s. 363.

27 Zgodnie z tezą uchwały SN z dnia 20 kwietnia 2006 r., III CZP 20/06, «Lex» nr 177078: „Nie jest dopuszczalna droga sądowa do dochodzenia przez komornika należności z tytułu kosztów egzekucyjnych ustalonych prawomocnym postanowieniem komornika, wydanym przeciwko dłużnikowi egzekwowanemu w stosunku do osób trzecich, które zobowiązały się je pokryć w drodze przejęcia długu". 
Wynagrodzenie dozorcy należy bowiem zaliczyć do wydatków, o których mowa w art. 39 ust. 2 pkt 4 u.k.s.e. Komornik na podstawie art. 770 k.p.c. ma obowiązek wydania postanowienia o ustaleniu kosztów egzekucji, które podlegają egzekucji na podstawie art. $770^{1}$ k.p.c. Za sprzeczne z wykładnią art. $770-770^{1}$ k.c. należy uznać dochodzenie kosztów egzekucyjnych w drodze procesu cywilnego.

Należy także uwzględnić przepisy k.p.c. regulujące zasady ponoszenia kosztów w procesie, które mają odpowiednie zastosowanie do postępowania egzekucyjnego na podstawie odesłania zawartego $\mathrm{w}$ art. 13 § 2 k.p.c. W piśmiennictwie wyróżnia się zasadę koncentracji i unifikacji kosztów, wyrażoną w art. $108 \S 1$ k.p.c., zgodnie z którą ,sąd ma obowiązek objęcia orzeczeniem końcowym wszystkich kosztów"28. Jak podkreśla H. Ciepła, zasada unifikacji i koncentracji kosztów procesu zapobiega rozdrobnieniu ich według wyników pojedynczych środków zaczepnych i obronnych ${ }^{29}$.

Wykładnia systemowa pozwala również na sięgnięcie do przepisów k.p.k. regulujących koszty sądowe w postępowaniu karnym ${ }^{30}$. SN opowiada się za niedopuszczalnością dochodzenia kosztów postępowania karnego w oddzielnym procesie cywilnym ${ }^{31}$.

28 A. Zieliński, Postępowanie cywilne. Kompendium, Warszawa 2010, s. 86.

29 H. CiepŁA, [w:] Kodeks postepowania cywilnego, I: Komentarz do art. $1-505^{14}$, red. K. PiAsecki, Warszawa 2006, s. 461.

30 Zasady ponoszenia kosztów procesu karnego uregulowane zostały w dziale XIV Kodeksu postępowania karnego (art. 616-645 k.p.k.). Koszty powyższe zostały podzielone na: 1) koszty sądowe, 2) uzasadnione wydatki stron, w tym z tytułu ustanowienia w sprawie jednego obrońcy lub pełnomocnika (art. $616 \S 1$ k.p.k.). Koszty sądowe są to opłaty oraz wydatki poniesione przez Skarb Państwa od chwili wszczęcia postępowania (art. 616 § 2 k.p.k.). Ustawodawca nie zawarł zupełnego katalogu wydatków Skarbu Państwa, ograniczając się do podania przykładów takich wydatków (art. 618 § 1 k.p.k.). Do wydatków Skarbu Państwa zaliczono m.in. wypłaty dokonane z tytułu przechowania zajętych przedmiotów (art. $618 \S 1$ pkt 4 k.p.k.). W postępowaniu przygotowawczym organem ustalającym wydatki jest prokurator, nawet w przypadku umorzenia postępowania, a w razie niezakończenia postępowania na tym etapie i kontynuowania sprawy w procesie sądowym, o kosztach procesu powinien rozstrzygnąć sąd w orzeczeniu kończącym postępowanie w sprawie (art. 626 i 627 k.p.k.).

31 Zgodnie z tezą uchwały SN z dnia 9 lutego 2007 r., III CZP 161/06, «Lex» nr 212445: „Nie jest dopuszczalna droga sądowa przed sądem cywilnym dla dochodze- 
Odnosząc powyższe uwagi do postępowania egzekucyjnego można stwierdzić, że art. 770 k.p.c. wprowadził zasadę koncentracji i unifikacji kosztów postępowania egzekucyjnego, która obejmuje wszystkie koszty, w tym także koszty związane $\mathrm{z}$ wynagrodzeniem dozorcy $\mathrm{w}$ razie oddania jemu rzeczy ruchomej pod dozór. Za sprzeczne z powyższą zasadą należy zatem uznać dochodzenie kosztów w odrębnym postępowaniu.

\section{MoŻLIWOŚĆ OBCIĄŻENIA WIERZYCIELA KOSZTAMI EGZEKUCJI}

Zgodnie z art. 770 k.p.c. „Dłużnik powinien zwrócić wierzycielowi koszty niezbędne do celowego przeprowadzenia egzekucji. Koszty ściąga się wraz z egzekwowanym roszczeniem. Koszt egzekucji ustala postanowieniem komornik, jeżeli przeprowadzenie egzekucji należy do niego. Na postanowienie sądu przysługuje zażalenie stronom oraz komornikowi".

W orzecznictwie SN nie budzi wątpliwości wykładnia art. 770 k.p.c., iż w postępowaniu egzekucyjnym zasada odpowiedzialności za wynik postępowania, jaka występuje w procesie (art. 98 k.p.c.) została zastąpiona zasadą, zgodnie z którą koszty postępowania egzekucyjnego ponosi dłużnik ${ }^{32}$. Podobnie w piśmiennictwie panuje zgodność co do tego, że w art. 770 k.p.c. wprowadzona została zasada odpowiedzialności dłużnika za koszty egzekucji, a tym samym nie obowiązuje podstawowa zasada dotycząca kosztów w procesie, którą stanowi ponoszenie kosztów przez stronę przegrywającą sprawę ${ }^{33}$.

nia przez osobę godną zaufania w rozumieniu art. $228 \S 1$ k.p.k. wynagrodzenia za przechowanie rzeczy oddanej jej na przechowanie w trybie określonym w tym przepisie".

32 Zob. rozważania zawarte w uzasadnieniu uchwały z dnia 29 lutego 1996 r., III CZP 17/96, «Lex» nr 24101.

33 Por. m.in. K. Flaga-GieruszyńsKa, op. cit., s. 1234. Komentując art. 770 k.p.c. E. WeNGEREK, op. cit., s. 147 stwierdził, iż: „Unormowanie sprawy kosztów w postępowaniu egzekucyjnym ogranicza się do zastąpienia zasady odpowiedzialności za wynik sprawy zasadą odpowiedzialności dłużnika za koszty egzekucji, podkreśleniem istnienia zasady kosztów celowych, zobowiązaniem komornika do ustalania kosztów w odrębnym postanowieniu oraz przyznaniem zażalenia na postanowienie sądu". 
Ustawa z dnia 22 lipca 2010 r. ${ }^{34}$ zmieniła przepis art. 42 ust. 2 u.k.s.e., który uzyskał brzmienie: „W przypadku gdy postępowanie egzekucyjne okaże się w całości lub w części bezskuteczne, wydatki poniesione przez komornika, które nie zostały pokryte z wyegzekwowanej części świadczenia, obciążają wierzyciela. Przepis art. 49 ust. 3 stosuje się odpowiednio". W art. 49 ust. 4 u.k.s.e. ustawodawca dopuścił możliwość uiszczenia przez wierzyciela opłat, o których mowa w ust. 1 i 2, $\mathrm{W}$ razie niecelowego wszczęcia postępowania egzekucyjnego.

Należy podkreślić, że art. 42 ust. 2 u.k.s.e. odnosi się wyłącznie do wydatków, a art. 49 ust. 4 u.k.s.e. do opłat. Obciążenie wierzyciela także innymi kosztami postępowania egzekucyjnego, w tym np. wynagrodzeniem pełnomocnika dłużnika, jest możliwe na podstawie przepisów art. 98 i nn. k.p.c. stosowanych do postępowania egzekucyjnego na podstawie odesłania zawartego w art. $13 \S 2$ k.p.c. Ponadto, należy pamiętać, że ustawodawca dopuszcza obciążenie wierzyciela wydatkami w przypadku bezskuteczności egzekucji. Pojęcie bezskuteczności należy odróżnić od niecelowości prowadzenia egzekucji, która może stanowić podstawę obciążenia wierzyciela kosztami egzekucyjnymi zgodnie z art. $98 \S 1$ k.p.c. w zw. z art. $13 \S 2$ k.p.c. lub też obciążenia wierzyciela opłatami (art. 49 ust. 4 u.k.s.e.).

Jeżeli sąd rozpoznający skargę na czynność komornika, którą stanowi postanowienie ustalające koszty egzekucji komorniczej ${ }^{35}$, dojdzie do przekonania, że koszty postępowania egzekucyjnego nie były celowe, np. w razie umorzenia postępowania egzekucyjnego, podstawę rozstrzygnięcia powinien stanowić nie art. 770 k.p.c., ale ogólne reguły dotyczące ponoszenia kosztów wskazane w art. 98 i nn. k.p.c.,

34 Dz.U. Nr 155, poz. 1038.

35 Zgodnie z tezą uchwały SN z dnia 28 kwietnia 2004 r., III CZP 16/04, «Lex» nr 106571: „Rozstrzygnięcie o kosztach niezbędnych do celowego przeprowadzenia egzekucji należy do sądu rozpoznającego skargę na postanowienie o ustaleniu kosztów egzekucji”. Zob. także postanowienie SN z dnia 29 listopada 2005 r., III CZP 102/05, «Lex» nr 177297. Dopuszczalność obciążenia wierzyciela kosztami egzekucji przez sąd rozpoznający skargę na czynności komornika dopuszcza także doktryna. Por. m.in. D. ZAWISTOWSKI, op. cit., s. 166. 
które mają odpowiednie zastosowanie do postępowania egzekucyjnego na podstawie odesłania zawartego w art. $13 \S 2$ k.p.c.

SN wskazuje, że odejście od zasady odpowiedzialności dłużnika za koszty egzekucji jest możliwe, co zakłada odpowiednie stosowanie art. 98 i nn. k.p.c. w zw. z art. $13 \S 2$ k.p.c., ale nałożenie na wierzyciela obowiązku zwrotu kosztów dłużnikowi zależy od oceny zachowania się wierzyciela i dłużnika w konkretnym przypadku ${ }^{36}$.

\section{WNIOSKI}

- Wydaje się, że nie ma powodów do odejścia od stanowiska wyrażonego przez SN, zgodnie z którym niedopuszczalne jest dochodzenie w oddzielnym procesie kosztów egzekucyjnych (zob. wyrok SN z dnia 14 czerwca 1973 r., I CR 250/73; postanowienie SN z dnia 29 listopada 2005 r., III CZP 102/05).

- Postępowanie egzekucyjne prowadzone przez komornika ma charakter publicznoprawny, albowiem stosunki łączące komornika z uczestnikami tego postępowania mają taki charakter (por. uchwała SN z dnia 22 października 2002 r., III CZP 65/02; uchwała SN z dnia 20 kwietnia 2006 r., III CZP 20/06). Taki charakter ma także stosunek łączący komornika z dozorcą zajętej ruchomości, jeżeli ruchomość została oddana dozorcy na podstawie postanowienia komornika. W powyższej sytuacji nie powstaje stosunek cywilnoprawny między wierzycielem a dozorcą, a stosunek publicznoprawny między komornikiem a dozorcą. Dozorca nie może zatem dochodzić na drodze procesu cywilnego wynagrodzenia od wierzyciela. W żadnym przypadku postanowienie komornika o oddaniu zajętej rzeczy ruchomej pod dozór nie prowadzi do powstania sto-

36 Por. np. z uchwałą SN z dnia 28 kwietnia 2004 r., III CZP 16/04, «Lex» nr 106571; postanowieniem SN z dnia 29 listopada 2005 r., III CZP 102/05, «Lex» nr 177297; uchwałą SN z dnia 4 sierpnia 2005 r., III CZP 51/05, «Lex» nr 152423: uchwałą SN z dnia 19 lipca 1996 r., III CZP 80/96, «Lex» nr 25827 oraz z dnia 6 września 2001 r., III CZP 39/01, «Lex» nr 48904; uchwałą składu siedmiu sędziów SN z dnia 27 listopada 1986 r., III CZP 40/86, «Lex» nr 3242, mającą moc zasady prawnej. 
sunku zobowiązaniowego o zwrot wynagrodzenia między dozorcą a wierzycielem, albowiem wynagrodzenie stanowi jeden z kosztów egzekucji, który podlega rozliczeniu w postępowaniu egzekucyjnym. Przepisy k.p.c. regulujące oddanie rzeczy pod dozór wskazują, iż między komornikiem a dozorcą nie istnieje równorzędność podmiotów typowa dla stosunków cywilnoprawnych.

- Za niedopuszczalnością dochodzenia w odrębnym procesie kosztów egzekucji, w tym wynagrodzenia dozorcy, przemawia zasada koncentracji i unifikacji kosztów postępowania egzekucyjnego wyrażona w art. 770 k.p.c.

- Dozorca może być uprawniony do dochodzenia od wierzyciela wynagrodzenia za dozór w odrębnym postępowaniu, jeżeli wiązał go z wierzycielem stosunek cywilnoprawny, którego źródłem jest np. umowa przechowania. Nie ma przeszkód, ażeby taka umowa została zawarta w toku postępowania egzekucyjnego. Wynagrodzenie dozorcy nie jest w powyższym przypadku zaliczane do kosztów egzekucji.

- Obciążenie kosztami egzekucji wierzyciela, jeżeli koszty takie okazały się niecelowe, należy odróżnić od obciążenia kosztami egzekucji wierzyciela z powodu bezskuteczności. W pierwszym przypadku wchodzi w grę zastosowanie do postępowania egzekucyjnego art. $98 \S 1$ k.p.c. w zw. z art. $13 \S 2$ k.p.c., oraz art. 49 ust. 4 u.k.s.e., a w drugim - przepisów art. 42 ust. 2 u.k.s.e.

The Caretaker's Fee for the Custody of Movables in Foreclosure

\section{Summary}

In compliance with the relevant Polish provisions, movables impounded by a bailiff are to be left in the custody of the person with whom they were found. In Article 855 of the Polish Code of Civil Procedure the legislator recognises the bailiff's option to put 
impounded movables in the custody of another person, including a creditor, who then performs the duties of caretaker of the impounded movables. The aim of this article is to present issues related to the caretaker's fee in foreclosure proceedings. When a movable item is entrusted to the custody of a third party a regulatory relation in public law arises between the bailiff and the caretaker. The caretaker's fee is part of the costs of repossession, and are payable in the foreclosure proceedings. The costs of repossession, including the caretaker's fee, may not be claimed in separate proceedings.

Słowa kluczowe: dozorca rzeczy ruchomych, postępowanie egzekucyjne, koszty egzekucji

Keywords: caretaker of the impounded movables, foreclosure proceedings, costs of repossession 